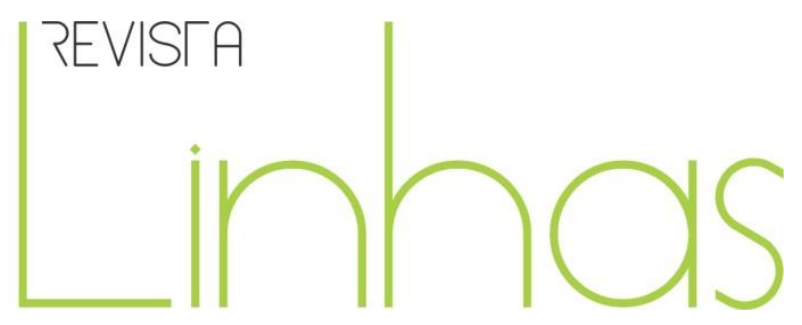

\title{
Narrativas sobre a formação docente para a escola primária de Santa Catarina (1935-1965) ${ }^{1}$
}

\section{Resumo}

O artigo apresenta a narrativa de professoras integrantes de uma congregação religiosa católica feminina, em sua gênese denominada Companhia das Catequistas, instituída em Rodeio (SC). Por meio de suas memórias, abordo o processo de formação docente desse grupo de professoras que estiveram presentes no cenário educacional catarinense na segunda metade do século XX. Em termos teóricos e metodológicos, sob as lentes de Berger e Luckmann (1985), procuro compreender como essa instituição construiu uma historicidade e adquiriu uma identidade religiosa e escolar por meio da formação docente de suas integrantes. Maurice Halbwachs (2003) foi tomado como matriz referencial para a análise relativa à memória coletiva, e Michel Pollak (1989; 1992), na análise referente à relação entre memória e identidade. Além das entrevistas, outros documentos, como, por exemplo, relatórios anuais, crônicas, atas, planos de aula, fichas funcionais, Livros Tombos, imagens e manuais didáticos, foram utilizados como fontes. Nas narrativas, ficou evidente que a formação docente contribuiu para a efetivação dessas professoras na carreira pública no Estado pois elas atendiam à carência de professores em escolas mais distantes, principalmente em áreas rurais. No geral, a formação docente era articulada à identidade religiosa, isto é, a formação docente era compreendida como secundária, o mais importante, para essas religiosas, era a formação católica, quer dizer, ser professora catequista era acima de tudo ser religiosa.

Palavras-chave: Formação docente. Memória. Identidade. Professores Cristãos. Companhia das Catequistas - Rodeio (SC).

\section{Geane Kantovitz}

Universidade Estadual do Norte do Paraná - UENP - Jacarezinho/PR Brasil geaneks@hotmail.com

\section{Para citar este artigo:}

KANTOVITZ, Geane. Narrativas sobre a formação docente para a escola primária de Santa Catarina (19351965). Revista Linhas. Florianópolis, v. 21, n. 46, p. 273-303, maio/ago. 2020.

\section{DOI: $10.5965 / 1984723821462020273$}

http://dx.doi.org/10.5965/1984723821462020273

\footnotetext{
${ }^{1} \mathrm{O}$ artigo apresenta o resultado parcial da tese intitulada Irmãs Catequistas Franciscanas: memórias sobre a prática docente no Ensino Primário de Santa Catarina (1935-1965), realizada no Programa de Pós-Graduação em Educação da Universidade Federal de Santa Catarina (UFSC) na linha de pesquisa Sociologia e História da Educação, sob a orientação da professora Dra. Clarícia Otto.
} 


\title{
Narratives about teacher formation for primary school of Santa Catarina (1935-1965)
}

\begin{abstract}
The article shows the narrative of teachers from a feminine religious catholic congregation, with a denominated genesis of Catechists Company, instituted in Rodeo (SC). By means of their memories, I approach the process of teacher formation of this group of teachers, which were present in Santa Catarina's educational scenario in the second half of the twentieth century. In theoretical and methodological terms, through the lens of Berger and Luckmann (1985), I seek to comprehend how this institution built a historicity and acquired religious and scholar identity by means of teacher formation of their members. Maurice Halbwachs (2003) was taken as referential matrix for the analysis regarding collective memory, and Michel Pollak (1989;1992) for the analysis regarding the connection between memory and identity. In addition to the interviews, other documents such as annual reports, chronicles, minutes, lesson plans, handouts, Registry Books (Livros Tombos), images and textbooks were used as sources. It became clear in the narratives that the teacher formation contributed with the effectiveness of those female teachers in public carrier in the State, because they attended the lack of teachers in distant schools, mostly in rural areas. In general, teacher formation was articulated to the religious identity, that is, the teacher formation was comprehended as secondary, the most important for those religious women was the Catholic formation, or, in other words, to be catechist teacher was, above all, to be religious.
\end{abstract}

Keywords: Teacher formation. Memory. Identity. Christian teachers. Catechists Company - Rodeio (SC). 
Por meio das narrativas das integrantes da atual Congregação das Irmãs Catequistas Franciscanas (CICAF), com idades entre 77 e 94 anos, o artigo aborda o processo de formação docente no período de 1935 a 1965, de religiosas que atuaram nas escolas primárias de Santa Catarina². Articulada à questão central, busco compreender a relação entre os processos de construção de suas memórias e a constituição identitária desse grupo de professoras, afinal, suas memórias reportaram-se diretamente às experiências vividas no interior do grupo que as constituiu, vale dizer, para os tempos de formação na $\mathrm{CICAF}^{3}$.

Em termos teóricos e metodológicos, sob as lentes de Berger e Luckmann (1985), procuro compreender como essa instituição construiu uma historicidade e adquiriu uma identidade religiosa e escolar por meio da formação docente de suas integrantes. Halbwachs (2003) foi tomado como matriz referencial para a análise das memórias dessas professoras. Assim, as memórias das entrevistadas foram trabalhadas na esteira do conceito de memória coletiva, cunhado por Halbwachs, o qual enfatiza a necessidade de se estudar os quadros sociais (lugares de convívio e de experiência) como condição para se estudar os indivíduos. Na esteira de Pollak (1989; 1992), busca-se dialogar com a identidade e sua construção, ou seja, com o enquadramento da memória e de seus processos de coesão.

O recorte temporal justifica-se por ser o ano de 1935 o período inicial em que as irmãs entrevistadas entraram na Congregação. Atrelada a essa justificativa, em janeiro de 1935 inicia-se no estado de Santa Catarina a Reforma Trindade, que empreendeu uma reforma no sentido de difundir as diretrizes pedagógicas por meio da formação de

\footnotetext{
${ }^{2}$ Esta pesquisa recebeu financiamento da Coordenação de Aperfeiçoamento de Pessoal de Nível Superior (CAPES) e Fundação de Amparo à Pesquisa e Inovação do Estado de Santa Catarina (FAPESC).

3 O texto apresenta parte dos resultados da pesquisa de doutorado realizada no Programa de PósGraduação em Educação, da Universidade Federal de Santa Catarina (UFSC). O projeto de pesquisa foi submetido ao Comitê de Ética em Pesquisa com Seres Humanos da instituição, à qual está vinculado, e aprovado pelo referido Comitê. As entrevistas foram gravadas e transcritas. Exceto uma delas, nove entrevistadas autorizaram a utilização de seus nomes, e todas assinaram o Termo de Consentimento Livre e Esclarecido (TCLE). Sendo assim, apenas o nome "Irmã Violeta" é um pseudônimo.
} 
professores, a qual influenciou diretamente as Irmãs Catequistas, pois elas tiveram de se adaptar, ocasionando uma mudança na perspectiva da formação docente da Companhia4.

O recorte finda em 1965 por representar uma fase de presença prioritária das irmãs nas escolas. Ou seja, a partir de 1965, inicia-se um período de significativas mudanças na Congregação; dentre as principais, está a saída de expressivo número de catequistas das escolas para outros serviços pastorais em geral, incluindo a abertura de casas em outros estados do país e além fronteiras. É importante ressaltar que, mesmo com essas transformações, as irmãs continuam atuando nas escolas primárias do estado, porém, em número menor.

O uso das fontes orais pareceu-me um percurso teórico e metodológico pertinente para conhecer um tempo de escola. Corroboro aqui com as contribuições de Ferreira e Amado (2006) no que diz respeito à história oral ao afirmar que, sob o ponto de vista metodológico, ela estabelece e ordena procedimentos de trabalho, funcionando como uma ponte entre a teoria e a prática, isto é, essa metodologia não se reduz aos processos práticos/técnicos, mas sim, quando conjugada com a teoria, possibilita a produção do conhecimento histórico, pois "é a teoria que oferece os meios para refletir sobre esse conhecimento, embasando e orientando o trabalho dos historiadores." (FERREIRA; AMADO, 2006, p. 17). Ainda de acordo com as autoras, as soluções e explicações devem ser buscadas na teoria da história, uma vez que ela dispõe de instrumentos capazes de compreender determinados tipos de comportamentos, pois se dedica, entre outros assuntos, "a pensar os conceitos de história e memória, assim como as complexas relações entre ambos." (FERREIRA; AMADO, 2006, p. 16, grifo do autor).

Nessa linha de compreensão, suas memórias direcionam a análise em consonância com a formação de uma identidade tanto individual quanto coletiva que se construía e reconstruía continuamente conforme suas vivências no grupo de pertencimento. Ao mencionar a identidade como elemento produzido pela memória, encontro em Pollak (1989; 1992) um fio condutor na discussão acerca da relação entre memória e identidade.

\footnotetext{
${ }^{4}$ A Reforma Trindade, por meio do Decreto $n^{\circ} 713$ (SANTA CATARINA, 1935), foi empreendida por Luiz Sanchez Bezerra da Trindade, indicado pelo governador Aristiliano Ramos para dirigir o Departamento de Educação, subordinado à Secretaria de Interior e Justiça. Juntamente com Trindade, também atuaram na Reforma Elpídio Barbosa (Subdiretor técnico) e João dos Santos Areão (Inspetor Federal das Escolas Subvencionadas e Nacionalização do ensino).
} 
Pollak (1992) ressalta que a memória é um fenômeno construído, consciente ou inconscientemente, como resultado do trabalho de organização, individual ou social. $\mathrm{Na}$ concepção do autor, o sujeito constrói não só uma imagem de si, mas também a percepção que deseja passar aos outros. Assim sendo, existe uma ligação entre a memória e a identidade.

O enquadramento da memória é outra expressão cunhada por Pollak (1989). Segundo o autor, além de servir como um referencial do passado, o enquadramento da memória revela uma forma de manter a coesão dos grupos sociais por meio da sua cristalização ou de seus marcos. Dessa forma, a memória integra-se

[...] em tentativas mais ou menos conscientes de definir e de reforçar sentimentos de pertencimento e fronteiras sociais entre coletividades de tamanhos diferentes: partidos, sindicatos, igrejas, aldeias, regiões, clãs, famílias, nações, etc. A referência ao passado serve para manter a coesão dos grupos e das instituições que compõem uma sociedade, para definir seu lugar respectivo, sua complementariedade, mas também as oposições irredutíveis. (POLLAK, 1989, p. 9)

O processo de enquadramento da memória da Congregação, ou das suas integrantes, depende dos mecanismos de justificação e das memórias individuais ou coletivas impostas e defendidas para dar coerência/credibilidade à historicidade da instituição. Quer dizer, o trabalho de enquadramento é certamente um mecanismo importante para a perenidade da organização social e das estruturas institucionais da CICAF.

Assim sendo, procuro entender como se instituem as memórias das Irmãs Catequistas entrevistadas, seus enquadramentos e como se articulam novas formas de organizá-las por meio das narrativas, ou, ainda, quais memórias foram solidificadas e enquadradas, constituindo-se como memória coletiva no que se refere à formação docente. Para tanto, o texto é desenvolvido em dois momentos. Num primeiro, contextualizo historicamente a fundação da Companhia da Catequistas, em 1915, a qual permaneceu com essa nomenclatura até 1958, quando se institucionalizou como Congregação das Irmãs Catequistas Franciscanas. No segundo momento, trago à baila suas memórias acerca da formação docente, a qual contribuiu na constituição de uma 
cultura escolar específica que se desenvolveu nas salas de aulas do ensino primário por elas geridas.

\section{A fundação da Companhia das Catequistas}

Oficialmente, a Congregação das Irmãs Catequistas Franciscanas, sob a então denominação de Companhia das Catequistas, foi fundada em 14 de janeiro de 1915 no município de Rodeio (SC)5. Todavia, o processo de sua criação iniciou-se em 1913. Diante das constatações a respeito da existência de muitas escolas paroquiais na região do Médio Vale do Itajaí-Açu (SC) e da crise dessas escolas por falta de professores e, ao mesmo tempo, de contratar novos docentes para as referidas escolas, o frei Polycarpo Schuhen, ${ }^{6}$ então vigário de Rodeio, em 1913, fez um convite a uma jovem chamada Amábile Avosani, que era integrante da Ordem Terceira de São Francisco e da Pia União das Filhas de Maria, para assumir a função de professora nas escolas paroquiais ${ }^{7}$. Amábile Avosani, após aceitar o convite e ser orientada para a docência pela irmã Clemência Beninca, religiosa da Divina Providência, congregação que, em 1905, havia fundado o Convento Menino Deus, em Rodeio, começou a lecionar na escola de Aquidaban, atual município de Apiúna (SC), sob a presença constante do clero franciscano.

Em 1914, o frei Polycarpo convidou mais duas moças para lecionarem nas escolas paroquiais, Maria Avosani e Liduína Venturi. Ambas também passaram pela preparação da

\footnotetext{
${ }^{5}$ O município de Rodeio (SC), localizado no Médio Vale do Itajaí-Açu, caracteriza-se pela presença de imigrantes italianos, o que facilitou a emergência da Companhia em razão do eixo religioso católico já presente entre os moradores. Seidt (2008, p. 79) esclarece que a religião, como eixo estruturador da vida familiar e comunitária das colônias, funcionava "como fator decisivo de identificação cultural", isto é, a religião católica e o sistema colonial italiano eram mecanismos de agregação cultural, favorecendo, assim, o surgimento de ordens religiosas.

${ }^{6}$ Polycarpo Schuhen nasceu em 17 de outubro de 1873, na cidade de Recklinghausen, Alemanha. Aos oito anos de idade, ingressou com os franciscanos no Seminário de Harreveld. Foi ordenado sacerdote na catedral de Paderborn, Alemanha, em 23 de maio de 1899. Com 26 anos de idade, em 20 de julho desse ano, chegou à Bahia, somando, com seus confrades, um grupo de onze franciscanos missionários. Na Bahia, concluiu seus estudos de teologia. Chegou a Rodeio (SC) em 1903. Polycarpo Schuhen era integrante da Ordem dos Frades Menores (OFM), Ordem Franciscana que chegou ao estado catarinense em 1891. A OFM assume os projetos de restauração da própria Ordem Franciscana no Brasil e o de expansão do ultramontanismo, de acordo com as determinações da Sé Romana.

7 Para compreender o processo de construção e expansão das escolas paroquiais em Santa Catarina, ver: HEERDT, Moacir. As escolas paroquiais em Santa Catarina (1890-1930). 1992. 220 f. Dissertação (Mestrado em História) - Centro de Filosofia e História, Universidade Federal de Santa Catarina, Florianópolis, 1992 e SOUZA, Rogério Luiz. As Escolas Paroquiais. In: DALLABRIDA, Norberto (org.). Mosaico de escolas: modos de educação em Santa Catarina na Primeira República. Florianópolis: Cidade Futura, 2003.
} 
Irmã Clemência e assumiram a função juntamente com Amábile. Diante do convite do frei, as três voluntárias afirmaram sua atuação como professoras nas escolas paroquiais. Em 1915, quando a existência dessas professoras foi levada ao conhecimento do bispo de Florianópolis (SC), Dom Joaquim Domingues de Oliveira, este reconheceu e sentenciou: "As professoras terceiras vivendo em certa comunidade chamem-se Catequistas e, todas juntas, formem a Companhia das Catequistas" (LIVRO DAS CRÔNICAS DA CONGREGAÇÃO, 1915 apud VALANDRO, 1986, p. 27) ${ }^{8}$. Assim, em 14 de janeiro de 1915, a Companhia das Catequistas foi oficializada. Ao final desse mesmo ano, a Companhia já era composta por nove integrantes que se dedicavam à docência nas escolas paroquiais.

A fundação da Companhia das Catequistas emerge não somente em razão da falta de professores para as escolas paroquiais, mas também como uma consequência da disputa de poder entre os padres franciscanos, os líderes das escolas italianas Dante Alighieri9 e os condutores do movimento em prol das escolas públicas, iniciado em 1911 com Orestes Guimarães ${ }^{10}$. Além disso, o serviço prestado pelas Irmãs Catequistas surgiu da necessidade de a Igreja Católica manter-se ativa no cenário que se instaurava. Aos poucos, ampliou o número de integrantes e as áreas de atuação, inclusive, em 1917, as Irmãs Catequistas expandiram-se para o Alto Vale do Itajaí-Açu, tornando-se uma importante instituição para o atendimento de escolas primárias no interior do estado. No período que finda o recorte temporal da pesquisa, 1965, a Congregação contava com 404 integrantes e 720 aspirantes. ${ }^{11}$

\footnotetext{
8 Dom Joaquim Domingues de Oliveira nasceu em Vila Nova de Gaia, em 4 de dezembro de 1878. Foi nomeado bispo em 2 de abril de 1914 e empossado em 7 de setembro do mesmo ano, para a então diocese de Florianópolis, elevada à Arquidiocese de Florianópolis em 17 de janeiro de 1927, tendo sido seu primeiro arcebispo. Morreu em Florianópolis em 18 de maio de 1967.

${ }^{9}$ A Associação Dante Alighieri foi fundada em 1889 , por Giacomo Venezian, em Roma. De acordo com Otto (2006), o objetivo da Associação era manter os laços culturais e a identidade italiana por meio de escolas subvencionadas. Autores, como Otto (2006; 2011; 2012b) e Dallabrida (1993), descrevem detalhadamente todo o processo de instalação da rede de escolas italianas Dante Alighieri no Médio Vale do Itajaí-Açu e os conflitos emergidos entre o clero franciscano e líderes da Sociedade Dante Alighieri.

${ }^{10}$ Orestes Guimarães nasceu em 27 de fevereiro de 1871. Destacou-se na ocupação dos postos da instrução pública paulista e na publicação de obras sobre educação. De 1911 a 1918, foi Inspetor Geral do Ensino do Estado de Santa Catarina e, entre 1918 e 1931, foi Inspetor Federal das Escolas Subvencionadas pela União, no mesmo estado. Sobre sua atuação em Santa Catarina, ler: TEIVE, Gladys Mary. "Uma vez normalista, sempre normalista": a presença do método intuitivo ou lições de coisas na construção de um habitus pedagógico (Escola Normal Catarinense 1911-1993). 2005. 290 f. Tese (Doutorado em Educação) - Setor de Educação, Universidade Federal do Paraná, Curitiba, 2005.

${ }^{11}$ De acordo com dados fornecidos por e-mail, pela Irmã Ivonete Gardini, uma das conselheiras gerais da CICAF, atualmente a Congregação conta com 376 integrantes.
} 
No geral, a fundação da Companhia pode ser compreendida sob a égide do processo de Restauração Católica no Brasil por estar inserida numa realidade social marcadamente formada por imigrantes italianos católicos e pela necessidade, por parte da Ordem dos Frades Menores, de manter o controle religioso e educacional na região. Beneduzi (2008) afirma que havia incentivos para a vinda de imigrantes europeus para o Brasil, em especial de italianos, haja vista que traziam consigo a observância da nova política da Igreja Católica, de romanização. A vinda de ordens religiosas, ou a fundação de congregações aqui no país, representava o retorno e a consolidação do catolicismo tridentino e convidava à "europeização" e ao afastamento do catolicismo luso-brasileiro. Não somente o envio de ordens religiosas e congregações europeias chegaram em peso ao Brasil, mas também instituições religiosas foram fundadas em meio à restauração com a ajuda dos imigrantes italianos ${ }^{12}$. Dentre essas instituições, destaca-se a Companhia das Catequistas. Portanto, a fundação da Companhia emergiu nesse contexto católico trazido pelos imigrantes italianos, todavia, foi amalgamado por princípios franciscanos alemães ${ }^{13}$.

De acordo com Dallabrida (1993), a fundação da Companhia das Catequistas foi uma resposta à crise das escolas paroquiais, concorrendo para a superação da resistência de parcela da população local, especialmente algumas lideranças, relativamente ao clero franciscano de origem alemã, assim como uma estratégia para sanar a falta de professores nas escolas distantes das sedes da paróquia, da pequena cidade e/ou dos municípios. Porém, na perspectiva de Gascho (1998) e Valandro (1986; 1990), alguns aspectos diferenciam-se no que concerne à fundação da Companhia. Segundo as autoras, integrantes da Congregação das Irmãs Catequistas Franciscanas, a fundação da Companhia deu-se pela necessidade de manter a unidade católica por meio da catequese nas escolas paroquiais. Valandro (1986) salienta que as Irmãs Catequistas surgiram para prestar um serviço ao povo. Gascho (1998), na mesma linha de raciocínio, entende a fundação da Companhia como um serviço prestado ao povo e à Igreja Católica. Ou seja, a

\footnotetext{
${ }^{12}$ No que concerne à produção sobre a atuação educacional de outras ordens religiosas no Brasil e em Santa Catarina, assim como sobre o ultramontanismo e reforma católica, ler Otto e Souza (2008), Pinheiro e Bittencourt (2015), Carvalho (1994) e Leonardi (2010).

${ }^{13}$ A presença dos franciscanos alemães em Santa Catarina remete-se a 1891. Nesse ano, quatro franciscanos chegaram a Santa Catarina para dar continuidade ao projeto de romanização da Igreja Católica. Otto (2006) destaca que o vigário de Blumenau, José Maria Jacobs, desde que soube da chegada da Ordem Franciscana em Santa Catarina, insistiu para que os frades assumissem a direção da paróquia São Paulo e do Colégio São Paulo, da cidade de Blumenau, no Médio Vale do Itajaí-Açu. Ainda em 1891, chega a segunda expedição de frades.
} 
função das Irmãs Catequistas era ensinar e catequizar nas escolas paroquiais num primeiro momento, e, num segundo, nas escolas públicas.

No entanto, concomitantemente ao período em que a Companhia foi se estruturando, as escolas paroquiais em que essas religiosas trabalhavam estavam gradativamente passando para a esfera pública. Alguns fatores podem ser elencados como determinantes no fechamento desses locais de ensino. Em primeiro lugar, o fim das escolas paroquiais era iminente, uma vez que surgiram em oposição às ideias positivistas e liberais da primeira República; inclusive, essas escolas se encontravam no próprio prédio da igreja sob o domínio do clero (SOUZA, 2003). De acordo com Souza (2003), nas colônias estrangeiras, o professor, religioso, ou o membro responsável da escola paroquial, estimulava a cultura de origem, uma vez que se via isolada, o que ia de encontro aos interesses do Estado nacionalista. Era preciso erradicar essas escolas em que o ensino, na maioria das vezes, era rudimentar e pouco podia se fazer para formar uma mentalidade de brasilidade.

Em segundo lugar, pode-se dizer que o desaparecimento gradativo dessa rede de escolas, esteve relacionado à permissão do ensino religioso nas escolas públicas (SOUZA, 2003), antes restrito às escolas paroquiais. Em Santa Catarina, nas palavras de Souza (2003), na aproximação do Estado Republicano com o clero, as escolas públicas começaram a permitir o ensino religioso, e, dessa forma, o número de escolas paroquiais gradativamente decresceu, isto é, a escola pública tornava-se atrativa pela gratuidade e pela possibilidade da permanência dos princípios católicos. Embora o autor destaque que os arcebispos do Sul, nesse período, não deram importância às escolas paroquiais nas colônias estrangeiras, o que se verificou no Médio Vale do Itajaí-Açu, mais especificamente em Rodeio, foi uma intensa presença religiosa nessas escolas, inclusive, a formação da Companhia das Catequistas como resultado desse interesse educacional e religioso.

Mesmo que as escolas paroquiais tenham se mantido até o fim da década de 1930, a transição destas para a pública foi inevitável; no entanto, acordos possibilitaram a permanência das Irmãs Catequistas nas escolas públicas estaduais e/ou municipais. Otto (2012a) explica que, na década de 1930, aos poucos, Dom Joaquim Domingues de Oliveira foi doando o espaço físico das escolas paroquiais ao Estado e, como contrapartida, o 
governo catarinense passou a permitir o ensino religioso nas escolas da rede pública e fez "a negociação para a permanência das referidas professoras/catequistas nas escolas então transformadas em públicas" (OTTO, 2012a, p. 412). Nesse sentido, conforme Otto (2006, p. 170), as Irmãs Catequistas contribuíram não somente para a "manutenção e formação de bons católicos, como também de bons patriotas, interesse da elite republicana" daquele período.

Conquanto caracterizada como um grupo para fins educacionais e religiosos, a Companhia, inicialmente, não possuía regulamentos, nem mesmo normas de conduta. $O$ primeiro registro oficial sobre a Companhia das Catequistas está registrado no livro das Crônicas $^{14}$ da Congregação, de 1917. Nessa Crônica, estava anotado como deveria ser conduzido tal Grupo, assim como deveria ser a conduta de suas integrantes:

\begin{abstract}
Estas são simples donzelas cristãs de irrepreensível conduta e dotadas de um expressivo amor à juventude que somente por amor de Deus e sem interesse material se dedicam à educação da mocidade nas escolas paroquiais, e bem assim, quando necessário for, às obras de caridade, quer à cabeceira dos doentes, quer no serviço da casa de Deus, cuidando da limpeza das capelas e dos paramentos, etc. Todas são membros da Ordem Terceira do grande Patriarca São Francisco de Assis, vivendo em caridade, pobreza e obediência, porém não fazem votos, estando assim na possibilidade de entregar-se inteiramente à sua nobre vocação (e missão). (LIVRO DAS CRÔNICAS DA CONGREGAÇÃO, 1915 apud VALANDRO, 1986, p. 18)
\end{abstract}

O documento traz à tona o ideário de mulheres que deveriam fazer parte do grupo em questão: "simples donzelas cristãs de irrepreensível conduta”. Ou seja, embora o objetivo de frei Polycarpo estivesse atrelado às necessidades de atender às escolas paroquiais da região de Rodeio, essas jovens deveriam seguir normas e regras de conduta que estivessem de acordo com os dogmas religiosos. Em outros termos, frei Polycarpo impôs regras às integrantes da Companhia, que consistiam em morar duas a duas nas comunidades em que trabalhavam; ter uma vida simples no convívio com o povo; fazer orações diárias, como o terço católico e a via sacra; participar das missas aos domingos, já que eram impossibilitadas da missa diária devido à distância da sede ou da capela; ofertar

\footnotetext{
14 Desde a fundação da Companhia das Catequistas, os padres franciscanos, e posteriormente as Irmãs Catequistas, tinham por hábito registrar, em forma de crônicas, o cotidiano das suas vivências, suas origens, sua tradição, as quais expressavam a imagem que a Congregação queria passar de si para o outro, tanto no âmbito interno quanto externo.
} 
a catequese para Primeira Eucaristia; realizar as missas onde não havia a presença do padre; estudar no tempo livre; cultivar uma pequena roça e um jardim na comunidade; conservar a capela em ordem; usar roupas simples (nos primeiros anos, as catequistas usavam a mesma roupa comum a todas as mulheres da região de Rodeio: um vestido simples, geralmente de cor escura, comprido até o tornozelo e um laço branco atado à cabeça). Embora não fossem consideradas irmãs no sentido canônico, os ideais católicos eram evidentes quando se tratava dos costumes impostos a essas jovens. Como destaca Nunes (2010, p. 497), "os costumes conventuais e as formas de comportamento das religiosas deveriam ser diferentes para marcar essa distinção com o mundo", e era isso que o clero desejava: marcar fronteiras entre a realidade social religiosa e a realidade social leiga.

Essas orientações, seguidas pelas jovens que ingressavam na Companhia, levavam à produção de hábitos repetitivos, voluntária e involuntariamente, atribuindo significados e características ao grupo. Segundo Berger e Luckmann (1985), são os hábitos que criam tipificações. Essas tipificações produzidas pela Congregação eram social e culturalmente construídas pelos freis e pelas próprias irmãs. Isso permite considerar as especificidades de sua constituição histórica, assim como as singularidades e multiplicidades que foram se constituindo ao longo do período pesquisado (1935-1965) e, principalmente, compreender as ações de seus sujeitos como fruto de uma constante interação que produz e reproduz tipificações internas da própria CICAF.

Mediante as tipificações, a instituição vai consolidando uma identidade aos seus integrantes, como também os mecanismos de controle aos quais seus membros estão submetidos. Dessa maneira, de acordo com Berger e Luckmann (1985), a instituição adquire historicidade, ou, ainda, ela se torna uma instituição histórica. Por consequência, a partir do momento em que o grupo de jovens professoras institucionalizou-se e corporificou-se, consolidou-se como uma instituição religiosa e educacional.

Como instituição histórica, a CICAF foi submetida ao controle por meio de regulamentos que direcionavam as normas de conduta das suas integrantes ${ }^{15}$. Berger e

\footnotetext{
15 O USUALE, redigido em 1941, foi um dos documentos mais importantes que regulavam as normas, condutas e controle social sobre e pela instituição. O USUALE, palavra italiana que significa usual, foi um importante passo para regulamentar a vida das Irmãs Catequistas. As normas e costumes dispostos no documento estavam organizados em verbetes, por ordem alfabética e descritos tais como eram vividos, ou
} 
Luckmann (1985, p. 80) esclarecem que "dizer que um segmento da atividade humana foi institucionalizado já é dizer que este segmento da atividade humana foi submetido ao controle social". Considerando que as tipificações recíprocas das ações são construídas e compartilhadas, as normas de conduta estabelecidas pelo frei fundador, e posteriormente pelos estatutos e determinações oficiais, definiram papéis que teoricamente não seriam possíveis em outras situações, mas eram específicos de suas integrantes e naturalmente compartilhados por todas.

Nessa linha de argumentação, essas professoras foram estabelecendo uma identidade no interior do grupo. Nos primeiros anos da Companhia, as catequistas não faziam votos nem mesmo as promessas religiosas, simplesmente eram professoras. De acordo com frei Polycarpo Schuhen, elas não seriam religiosas. Bastava que fossem maestras, isto é, mestras, como eram comumente chamadas pelos colonos descendentes de italianos. Todavia, para que pudessem ser aceitas na Companhia, o frei estabeleceu um modo de vida que deveria ser seguido pelas integrantes e que caracterizasse uma singularidade no modo de viver, sobretudo de viver no meio do povo. Repetidas vezes o frei Polycarpo exclamava: "Sejam irmãs do povo!" (POLYCARPO, apud BRUNELLI, 2008, p. 301).

Efetivada a institucionalização da CICAF, a Companhia foi reconhecida não somente em Rodeio, mas também em outros territórios pelo seu estilo de vida, tanto religioso quanto educacional ${ }^{16}$. Conforme a instituição foi se corporificando, tanto em sua estrutura organizacional quanto por meio de regulamentos e normas, ela foi se definindo como uma instituição que procurava abarcar os aspectos religiosos e a educação primária no estado de Santa Catarina. As jovens que passaram a associar-se à Congregação, ao mesmo tempo em que assimilaram as normas institucionais, atuaram sobre as outras integrantes por meio de sua experiência e crenças religiosas. Quer dizer, elas são produtos e produtoras dessa ordem social construída por elas e para elas. As ações das Irmãs Catequistas foram determinadas por padrões específicos de conduta estabelecidos

como frei Bruno queria que elas vivessem. Exemplo: "Alunos: sejam tratados com imparcialidade. Em nenhum toquem nem acariciem. Se algum deles cair gravemente doente, podem visitá-lo uma vez [...]." (USUALE, 1941 apud VALANDRO, 1990, p. 197).

${ }^{16}$ Para aprofundar o estudo sobre a expansão do grupo para outras cidades, estados e países, ver Valandro (1986; 1990) e Gascho (1998). 
pelo grupo e, ao mesmo tempo, estabeleceram definições e ações no grupo. Essa relação sempre ocorreu num movimento constante, pois eram ordens sociais que foram edificando tipificações pelo grupo e pelo próprio sujeito.

Portanto, a CICAF gradativamente adquire uma identidade socialmente construída, e suas integrantes reproduzem as tipificações e estão sujeitas às normas de conduta. Todavia, para garantir a continuidade institucional, devem existir mecanismos de legitimação dessa ordem. No caso da CICAF, a formação docente apresentava-se como um mecanismo que deveria garantir a unidade identitária do grupo e legitimá-la como instituição educativa.

\section{A formação para ser professora}

Considerando que desde o início da Companhia algumas candidatas apresentavam-se ao frei Polycarpo e mal sabiam ler e escrever, a formação docente era um desafio. Muitas vezes, essas jovens eram aceitas em razão da necessidade de professores para atuarem nas escolas rurais e atender aos filhos dos colonos, assim como para manter valores e preceitos católicos no ensino. Nas memórias de duas entrevistadas, percebe-se essa necessidade de apressar a formação docente para atuarem em sala de aula. As entrevistadas lembraram que assumiram turmas antes de completarem 18 anos, inclusive, por esse motivo, não foram nomeadas pelo Estado, porque a legislação assim não permitia. Por conseguinte, era comum as catequistas assumirem salas de aula ainda antes de terem sido preparadas para tal ofício. Assim, foi fato corriqueiro as Irmãs Catequistas terem assumido salas de aula com pouca, ou nenhuma preparação.

De acordo com Valandro (1986), desde a fundação da Congregação, a formação para a docência era um desafio e enfrentava problemas por diversos fatores. O primeiro deles foi não haver uma estrutura organizacional de espaço físico e profissional para prepará-las, juntamente com a necessidade urgente de professores para lecionarem nas escolas primárias mais distantes dos centros das pequenas cidades ${ }^{17}$. Já o segundo fator era a impossibilidade de as irmãs frequentarem cursos de formação para a docência, mais especificamente, o curso normal destinado a formar professores para o ensino primário,

\footnotetext{
17 Vale lembrar que, nos primeiros anos de fundação, as irmãs Clemência e Ambrosina, da Divina Providência, supriram essa lacuna, o que se tornou insuficiente com o crescimento do grupo.
} 
uma vez que essas escolas eram distantes das casas da Congregação. De acordo com Valandro (1986), frei Bruno Linden, responsável pelas catequistas de 1926 a 1945, não tinha apreço pela formação intelectual delas. Segundo o frei, as professoras ficariam orgulhosas se estudassem, e isso iria contra os princípios de humildade e pobreza de São Francisco de Assis. Frei Bruno foi o responsável pelas catequistas no momento em que as escolas paroquiais estavam sendo substituídas pelas escolas públicas, e a Reforma Trindade exigia maior qualificação profissional dos envolvidos com a educação. ${ }^{18}$

Desse modo, a Reforma abordou as seguintes reformulações: as Escolas Normais foram transformadas em Institutos de Educação, que abrangiam Jardim de Infância, Grupo Escolar, Escola Isolada, Escola Normal Primária, Escola Normal Secundária e Escola Normal Superior Vocacional. As Escolas Normais Primárias, com um curso de três anos, destinavam-se a preparar professores para as zonas coloniais/rurais, eram as antigas Escolas Complementares; as escolas Normais Secundárias, com um curso também de três anos, exigiam que seus alunos fossem egressos das Escolas Normais Primárias; a Escola Normal Superior Vocacional, com alunos oriundos das Escolas Normais Secundárias ou que tivessem concluído a $5^{\text {a }}$ série no Colégio Pedro II, ou outro a ele equiparado; os egressos da Escola Normal Superior Vocacional, que funcionou apenas em 1938 e 1939, recebiam diploma de habilitação para o magistério, de preferência, nos Grupos Escolares e nas Escolas Normais Primárias.

Na perspectiva de Bombassaro e Silva (2011), a Reforma Trindade impulsionou a introdução dos métodos orientados pelo movimento da Escola Nova em Santa Catarina. No entendimento das autoras, umas das principais articulações para adequar o ensino catarinense aos métodos escolanovistas era a formação de professores por meio da inclusão de estudos científicos, principal objetivo da Reforma Trindade. Nessa mesma direção, Pereira e Daros (2013) destacam como apontamentos escolanovistas em Santa Catarina: a realização das Semanas Educacionais, as mudanças nos currículos dos cursos

\footnotetext{
${ }^{18}$ Em relação à Reforma Trindade, Bombassaro (2010, p. 318) destaca que "o novo professor, principal foco de preocupações dos intelectuais que propuseram a renovação educacional, deveria estar submetido a um processo formativo que o incorporasse ao projeto político, à medida que incutiria nele um perfil profissional enquadrado nas aspirações modernizadoras do movimento. Isso porque o movimento de reformulação dos princípios pedagógicos exigia a superação do professor supostamente formado em técnicas de ensino demasiado intelectualistas, incapaz, portanto, de levar a cabo o novo projeto de ampliação das possibilidades intervencionistas da instituição escolar. Era necessário à nova conjuntura que ele fosse capaz de propiciar aos educandos o contato com o maior número de experiências possível, pois, somente assim, poder-se-ia formar um cidadão socialmente hábil”.
} 
de formação de professores, a difusão de discursos afinados ao movimento em periódicos locais, como a Revista de Educação (publicada em 1936 e 1937 pelo estado de Santa Catarina) e a revista Estudos Educacionais (de autoria do Instituto de Educação de Florianópolis e fundada por João Roberto Moreira para ser lócus de discussão entre alunos, docentes e intelectuais da educação) $)^{19}$.

Nesse sentido, a partir do momento em que o Estado começa as reformas educacionais e, simultaneamente, reconhece o trabalho das Irmãs Catequistas para a educação de Santa Catarina, manteve-as professoras nas escolas públicas, exigindo a sua formação docente. Ou, ainda, o Estado legitimou a instituição e as suas integrantes como sujeitos numa outra ordem social: na escola pública primária catarinense.

Quando as irmãs entrevistadas começaram a trabalhar nas escolas, entre as décadas de 1930 e 1950, todas foram nomeadas para as escolas públicas estaduais e/ou municipais; dessa forma, tiveram de se adaptar à nova realidade social: o fim das escolas paroquiais e a estatização das escolas. Atrelada a esse movimento, a educação catarinense estava passando pela campanha de nacionalização iniciada em 1911 pela reforma Orestiana. Algumas medidas deveriam ser tomadas para evitar o estrangeirismo nas escolas, inclusive o cuidado em contratar professores que lecionassem na língua vernácula. Medidas essas que acabaram repercutindo também na formação docente das Irmãs Catequistas. Nos relatos, identifica-se o primeiro desafio com a estatização das escolas onde trabalhavam: o Exame de Habilitação.

$\mathrm{Na}$ fala da irmã Hedwiges ${ }^{20}$, o Exame de Habilitação estava presente quando se tratava de formação docente das irmãs:

\footnotetext{
19 Para aprofundar o conhecimento sobre o movimento da Escola Nova em Santa Catarina, ler: BOMBASSARO, Ticiana. O movimento pela Escola Nova em Santa Catarina: formação docente e modernização do ensino. Cadernos de História da Educação, [Uberlândia], v. 8, n. 1, p. 221-232, jan./jun. 2009; DANIEL, Leziany Silveira. João Roberto Moreira (1912-1967): itinerários para uma racionalidade ativa. 2009. 224 f. Tese (Doutorado em Educação) - Setor de Educação, Universidade Federal do Paraná, Curitiba, 2009 e BOMBASSARO, Ticiana; SILVA, Vera Lucia Gaspar da. Modernização do Estado e Reformas do Ensino: manifestações da Escola Nova em Santa Catarina. In: MIGUEL, Maria Elisabeth Blanck; VIDAL, Diana Gonçalvez; ARAUJO, José Carlos Souza. Reformas Educacionais: as manifestações da Escola Nova no Brasil (1920 a 1946). Campinas: Autores Associados; Uberlândia: EDUFU, 2011.

20 No momento da entrevista, a Irmã Hedwiges tinha 94 anos de idade, entrou na Companhia das Catequistas em 1937, com 15 anos de idade. Embora seu nome seja Jadwiga Szepanska, ela solicita que seja identificada como irmã Hedwiges, pois este é considerado o seu nome de religiosa.
} 
Era durante as férias aqui em Rodeio. Vinham dois inspetores e ajudavam na habilitação. Nós éramos em quarenta e poucas irmãs, então nós precisávamos. [...] o Exame de Habilitação não existe mais. Mas existia essa tal coisa que eu achava muito bom e sei que a maior parte das irmãs passavam. Nós éramos assistidas por dois inspetores, não era só um não. Eles chamavam, e faziam perguntas sobre Geografia, e a gente deveria saber a resposta. Sobre a História da Pátria eles diziam: 'A senhora me conta sobre tal história'. Então, a gente deveria contar. Matemática... a gente recebia por escrito, e a gente tinha que fazer, resolver. Português... era um ditado que eles faziam. Ditado até que eu passei muito bem, ganhei quase nove, oito vírgula alguma coisa. (IRMÃ HEDWIGES, 2014)

Nas memórias da irmã Hedwiges, chama a atenção a importância por ela atribuída ao Exame de Habilitação, demonstrando entusiasmo e orgulho; inclusive, ela levanta-se da cadeira como forma de satisfação ao se lembrar desse momento. Pareceu ter sido muito importante para ela e para a história da Congregação, já que "a maior parte das irmãs passava no Exame de Habilitação" (IRMÃ HEDWIGES, 2014). Nesse momento da narrativa, era a identidade do grupo que estava sendo preservada em suas memórias, pois rememorar que todas passavam no Exame era reafirmar a importância do seu grupo social para a história, e a memória que deveria ser preservada. A memória de si, para si e para o outro que a irmã construía expressava um sentimento de coerência em que os diferentes elementos que a formavam eram efetivamente unificados. Na perspectiva de Pollak (1992, p. 5), "a memória é um elemento constituinte do sentimento de identidade, tanto individual como coletiva, na medida em que ela é também um fator extremamente importante do sentimento de continuidade e de coerência de uma pessoa ou de um grupo em sua reconstrução de si”. Dessa forma, pode-se dizer que há uma unidade nos três elementos que propõe Pollak (1992), na unidade física, dentro do corpo e no sentimento de coerência. Logo, afirmar a conquista que aquelas irmãs tiveram no passado é reafirmar a continuidade do grupo no presente.

O Exame de Habilitação estava previsto no Decreto $n^{\circ}$ 58, de 28 de janeiro de 1931 (SANTA CATARINA, 1931), implantado pelo General Ptolomeu de Assis Brasil, interventor federal no estado de Santa Catarina. O decreto previa o seguinte em seus artigos 9 e 10: 
Art. 9 - A habilitação dos professores far-se-á perante banca examinadora de três membros, regularmente constituída, presidida pelo Diretor da Instrução.

Parágrafo único. Nos municípios em que funcionarem as escolas subvencionadas pela União, a presidência da banca caberá ao Inspetor Federal das Escolas Subvencionadas, sendo que neste caso os exames se realizarão na sede da referida inspetoria.

Art. 10 - Os exames para a habilitação dos professores das escolas estrangeiras versarão sobre as disciplinas que devem ser ministradas na língua vernácula, conforme o Art. $2^{\circ}$, especificados no decreto 1300, de 14 de novembro de 1919. (SANTA CATARINA, 1931)

De acordo com o Decreto, o governo catarinense estaria cumprindo as determinações federais quanto à nacionalização do ensino já vigentes desde 1919, principalmente em regiões de áreas de colonização. Assim, o Exame era uma forma encontrada para que os professores fossem considerados aptos para a docência pelo fato de lecionarem na língua vernácula. Neotti (2013, p. 90) destaca que nos exames de habilitação era averiguada "a competência para serem professoras em Língua Portuguesa".

Consequentemente, o Exame de Habilitação oportunizou o reconhecimento do trabalho desenvolvido pelas Irmãs Catequistas; não era suficiente, porém, era importante para mantê-las nas escolas e continuar o processo de institucionalização da Congregação. Era preciso avançar e procurar meios de formar as integrantes da CICAF para a docência, pois uma parte significativa delas ainda não tinha os cursos determinados de acordo com as exigências do Estado. No Quadro 1, é possível observar a formação das irmãs entrevistadas. 
Quadro 1 - Formação das Irmãs Catequistas entrevistadas no ano em que começaram a lecionar

\begin{tabular}{|l|l|l|l|}
\hline Entrevistadas & $\begin{array}{l}\text { Entrada na } \\
\text { Congregação }\end{array}$ & $\begin{array}{l}\text { Início da } \\
\text { docência }\end{array}$ & $\begin{array}{l}\text { Formação ao } \\
\text { iniciara } \\
\text { docência }\end{array}$ \\
\hline $\begin{array}{l}\text { Irmã Amélia } \\
\text { Pegoretti }\end{array}$ & 1946 & 1947 & Primário \\
\hline Irmã Cecília Back & 1951 & 1958 & $\begin{array}{l}\text { Normal } \\
\text { Regional }\end{array}$ \\
\hline Irmã Dália Tomelin & 1944 & 1947 & Complementar \\
\hline $\begin{array}{l}\text { Irmã Dorvalina } \\
\text { Tridapalli }\end{array}$ & 1935 & 1942 & Primário \\
\hline Irmã Geraldina Rover & 1939 & 1944 & Primário \\
\hline $\begin{array}{l}\text { Irmã Jadwiga } \\
\text { Szepanska } \\
\text { (Hedwiges) }\end{array}$ & 1937 & 1939 & Primário \\
\hline Irmã Maria Venturi & 1942 & 1945 & Primário \\
\hline Irmã Paula Oenning & 1947 & 1950 & Complementar \\
\hline Irmã Violeta & 1939 & 1946 & Complementar \\
\hline Irmã Verônica Haskel & 1946 & 1954 & Primário \\
\hline
\end{tabular}

Fonte: Valandro (1990) e entrevistas com as irmãs concedidas a Geane Kantovitz, 2015.

No Quadro 1, constata-se que seis das Irmãs Catequistas iniciaram a docência apenas com o curso primário. Valandro (1990) salienta que até os anos 50 do século XX, as professoras catequistas, na sua maioria, tinham somente as três primeiras séries desse curso. A duração do primário frequentado pelas irmãs era regida de acordo com o Decreto $n^{\circ} 1.322$, de 29 janeiro de 1920 (SANTA CATARINA, 1920), o qual determinava o Programa dos Grupos Escolares e das Escolas Isoladas do estado de Santa Catarina, definindo três anos de duração ao curso primário em escolas isoladas e quatro anos em grupos escolares ${ }^{21}$. Portanto, muitas das Irmãs Catequistas começaram a docência apenas com o curso primário de três anos, o que era incompatível com as exigências reformistas, cuja exigência era o curso complementar ou normal.

Essa organização do ensino foi modificada pela Lei Orgânica Estadual para o Ensino Primário do Estado de Santa Catarina de 1946 (SANTA CATARINA, 1946a), que o dividiu em duas categorias: o Ensino Primário Fundamental, subdividido em dois cursos, o Elementar, de quatro anos, e o Complementar, de um ou dois anos; e o Ensino Primário

\footnotetext{
${ }^{21}$ Tal orientação já aparece no Programa dos Grupos Escolares e das Escolas Isoladas do Estado de Santa Catarina. Aprovado e determinado observar pelo Decreto $n^{\circ} 587$, de 22 de abril de 1911.
} 
Supletivo para adolescentes, adultos e classes de alfabetização. Desse modo, no período em que as irmãs estudaram e no que lecionaram nas escolas isoladas, a duração do curso primário era de quatro anos ${ }^{22}$; todavia, o mesmo decreto facultava às escolas isoladas ministrar apenas os três primeiros anos do Curso Primário Elementar, podendo os alunos concluí-lo em outra escola, prática evidenciada pelas irmãs:

Eu não tinha bem completado 13 quando saí da aula, porque tinha só até terceiro ano naquele tempo, não existia o quarto ano. Em Taió, o inspetor conseguiu criar o quarto ano. Daí nós ficamos lá, uma turminha de meninas com as irmãs e fizemos o quarto ano do primário. (IRMÃ PAULA, 2014) $)^{23}$

Perante o desafio de manter-se ativa no cenário educacional catarinense, a CICAF estava diante de um dilema: formava suas integrantes para a docência ou perderia salas de aulas, e até escolas, para professores considerados leigos, do ponto de vista religioso, que tinham o curso complementar ou normal, os quais eram exigidos de acordo com a legislação vigente. Essa possibilidade de perder espaço nas escolas pode ser identificada nos relatos da irmã Hedwiges:

Eu fui nomeada numa escola estadual lá em Apiúna, que era Aquidaban, e como tinha um professor que tinha feito o complementar, nós perdemos a escola porque eu tinha só a quarta série. Ele tinha o direito da escola porque ele era complementarista e nós não éramos complementaristas, pois o complementar dava o direito de tomar uma escola, de ser nomeado, tudo certinho. Depois caiu fora o complementar e veio o normal, daí só quando fazia o normal é que podia assumir uma escola, daí podia, já o complementar ficou para trás. (IRMÃ HEDWIGES, 2014)

Percebe-se que as irmãs que tinham somente o curso primário estavam sujeitas a perder o seu espaço nas escolas. Quando a irmã mencionou que elas perderam a vaga para um professor complementarista, é possível notar a urgência da formação das irmãs. Era necessário buscar, no mínimo, o curso complementar. Tal curso, já frequentado pelas

\footnotetext{
${ }^{22}$ Segundo Beirith (2009, p. 191), "as escolas isoladas, instaladas nas zonas rurais e nos bairros populares, foram responsáveis pela escolarização de uma significativa parcela da população brasileira".

${ }^{23}$ No momento da entrevista, a Irmã Paula Oenning tinha 86 anos de idade e entrou na Companhia em 1947, quando tinha 16 anos. Sua família é de agricultores e de origem alemã. Embora não tenha tido professora catequista na sua infância, relatou que teve contato com as irmãs e as admirava muito. Ou seja, a presença delas na comunidade em que vivia teve influência na sua escolha.
} 
irmãs Violeta, Paula e Dália antes de iniciarem a docência, foi instituído pela Reforma

Orestes Guimarães. Tinha duração de dois ou três anos e formava professores para as escolas isoladas. Funcionava nos prédios dos grupos escolares e tinha por objetivo completar o ensino iniciado nessas escolas, assim como preparar candidatos para o magistério. O curso correspondia ao programa dos dois primeiros anos da Escola Normal. A conclusão do curso habilitaria o candidato a se matricular no último ano, terceiro ano, da Escola Normal (SANTA CATARINA, 1911).

Nas memórias das irmãs, o curso complementar esteve presente representando, assim, a importância para a formação e continuidade do grupo na área da educação. A irmã Dália lembrou:

A gente estudava em casa, tinha uma irmã que dava aula para nós, porque a gente tinha ido até a terceira série em casa, então ela dava aula igual como se fosse a quarta série para a gente se ambientar um pouco na escola. Depois fomos para Rodeio e ali começamos o complementar, que naquele tempo era de dois anos. Então a gente fez dois anos de estudo no Grupo e depois ficamos postulantes, noviças e ficamos irmãs em 1944. Depois fomos dar aula. (IRMÃ DÁLIA, 2014) ${ }^{24}$

Nessa mesma perspectiva, ao ser instigada a falar sobre a necessidade e exigências do Estado para estudar, a irmã Violeta (2015) ${ }^{25}$ também rememorou: "nesse momento, nós fomos as primeiras do grupo de meninas, de estudantes que conseguimos fazer o complementar. Isso já foi um começo! Depois, mais tarde, foi abrindo espaço, inclusive o normal". O curso complementar frequentado pelas irmãs foi no Grupo Escolar Osvaldo Cruz, fundado em Rodeio em 1942.

\footnotetext{
${ }^{24}$ No momento da entrevista, Irmã Dália Tomelin tinha 88 anos de idade, entrou na Congregação em 1944. Sua família é de origem italiana e trabalhava na agricultura. Lembrou que sua família era formada de "trabalhadores, plantadores de arroz e milho", e que o pai "tinha muitos anos de arroz e quase um quilômetro de arrozeira". Ficou evidente que a escolha de seguir a vida religiosa foi sua e viu na Congregação um caminho para ter acesso ao ensino formal.

${ }^{25}$ No momento da entrevista, a Irmã Violeta tinha 87 anos de idade e entrou na Companhia em 1939, com 12 anos de idade. De família italiana e agricultora, lembrou que na infância se comunicava somente com o dialeto italiano, tinha bastante dificuldade com o português. Em conversa informal, antes da entrevista, comentou que foi alfabetizada por uma Irmã Catequista e foi nesse período, quando ainda tinha seis anos de idade, que despertou o desejo de ser membro da CICAF. Violeta é um pseudônimo, visando manter o anonimato, conforme solicitação feita pela irmã.
} 
O Grupo Escolar Osvaldo Cruz foi um importante local de formação das Irmãs Catequistas, pois ficava próximo à Casa Mãe ${ }^{26}$ e ofertava o curso complementar considerado indispensável, no período, para a permanência das irmãs nas escolas públicas. Frei Bruno assim relatou a fundação do Grupo: "O ano novo também nos trouxe o Grupo Escolar. Em 8 aulas (4 da manhã e 4 da tarde) se dá a instrução e educação. Em cada aula, duas catequistas davam doutrina três vezes por semana, 20 minutos (meia hora)" (LIVRO TOMBO I, 1942, p. 15). O frei referiu-se às oito salas de aulas que foram inauguradas no grupo escolar as quais eram assim distribuídas: três primeiros anos, um segundo ano, dois quartos anos e um primeiro ano complementar.

Embora a Reforma Trindade tenha substituído o curso complementar pelas escolas Normais Secundárias, o curso continuou sendo ministrado no Grupo Escolar Osvaldo Cruz. Segundo Fiori (1991), a Reforma Trindade não teve o mesmo impacto tido pela de Orestes Guimarães. Foi uma reforma que pouco frutificou por ser praticamente uma superestrutura administrativa e que nada introduziu de novo nos currículos escolares, redistribuiu-os apenas. A partir de 1938, leis e decretos foram aos poucos derrubando a Reforma Trindade. No entanto, a maior mudança ocorreu em 1946 por meio da Lei Orgânica do Ensino Normal no Estado de Santa Catarina (SANTA CATARINA, 1946b).

De acordo com Prates, Oliveira e Teive (2012), a Lei Orgânica do Ensino Primário do Estado de Santa Catarina (SANTA CATARINA, 1946a) contribuiu para a efetivação do movimento da Escola Nova nos estabelecimentos escolares catarinenses, iniciada na década de 1930 com a Reforma Trindade, ocasionando uma significativa mudança no processo de formação docente no estado catarinense. Esse decreto se desdobrou em outros, tais como o Decreto ${ }^{\circ} 3.732$, de 1946 (SANTA CATARINA, 1946c), que preconizava o Programa para o Ensino Primário; o Decreto $n^{\circ}$ 3.733, de 1946 (SANTA CATARINA, 1946d), que regulamentou o Serviço de Inspeção Escolar; e o Decreto n 3.735, de 1946 (SANTA CATARINA, 1946e), que regulamentou os estabelecimentos de ensino primário; este tratava de aspectos organizacionais e estruturais dessa modalidade de ensino, dentre eles a obrigatoriedade do funcionamento das instituições complementares da

\footnotetext{
${ }^{26}$ Casa Mãe ou Casa Matriz, construída em 1933, é a nomenclatura atribuída à casa sede da CICAF, a primeira residência oficial onde se reuniam nas primeiras décadas da Companhia.
} 
escola (PRATES; OLIVEIRA; TEIVE, 2012). Nessa direção, não obstante já divulgadas as

ideias escolanovistas no Brasil, em Santa Catarina o movimento adquire notoriedade apenas em meados da década de 1940 por meio desses decretos de Elpídio Barbosa ${ }^{27}$.

A Lei Orgânica do Ensino Normal no Estado de Santa Catarina determinou um padrão de ensino normal que já vinha sendo adotado em vários estados brasileiros, inclusive era uma adequação ao Decreto n 8.530, de 2 de janeiro de 1946 (BRASIL, 1946), que expede a Lei Orgânica do Ensino Normal no Brasil. Em Santa Catarina, assim ficou estruturada a formação docente: o Ensino Normal passou a ser ministrado em dois ciclos, o primeiro compreendeu o curso de Regentes de Ensino Primário, de quatro anos, e o segundo, o curso de Formação de Professores Primários, de três anos; o Ensino Normal passou a oferecer cursos de especialização para professores primários e cursos de habilitação para administradores escolares do grau primário; estabeleceu três tipos de estabelecimentos de Ensino Normal, o curso Normal Regional, a Escola Normal e o Instituto de Educação. O curso Normal Regional era o estabelecimento destinado a ministrar somente o primeiro ciclo do Ensino Normal; a Escola Normal era o estabelecimento a dar o curso do segundo ciclo e ciclo ginasial do ensino secundário; e o Instituto de Educação oferecia, além dos cursos próprios da Escola Normal, o ensino de especialização do magistério e de habilitação para administradores escolares de grau primário.

Diante dessas mudanças no cenário formativo de professores para o ensino primário catarinense, o curso complementar não era mais suficiente. Era necessário avançar novamente. O curso normal regional tinha o objetivo de formar o professor regente para o ensino primário. Funcionava nos prédios dos grupos escolares, geralmente no período noturno, ou comprimido nos períodos intermediários entre os turnos da manhã e tarde, ou entre o período da tarde e noite.

\footnotetext{
${ }^{27}$ Elpídio Barbosa foi uma figura do cenário educacional e político catarinense no século XX. Formado em direito, Barbosa atuou em diversos cargos, desenvolvendo e impulsionando os novos ideais de educação, inclusive foi defensor e propulsor da Escola Nova em Santa Catarina. Foi diretor do Departamento de Educação de Santa Catarina na década de 1940. Pertencia a uma elite econômica, social e intelectual catarinense. Elpídio Barbosa representava a ideia do intelectual no século XX, de um detentor do conhecimento que buscava aplicá-lo na sociedade em que estava inserido. Os ideais da Escola Nova foram uma das grandes bandeiras levantadas por Barbosa; romper com as barreiras do ensino tradicional e remodelar o processo de ensino e aprendizagem era uma de suas metas, perceptível ao longo de toda a sua atuação em cargos públicos (CUNHA; OLIVEIRA JUNIOR, 2015).
} 
Esse modo de organizar o estudo foi compreendido ao analisar o Decreto-Lei $\mathrm{n}^{\circ}$ 257 (SANTA CATARINA, 1946b), que expede a Lei Orgânica do Ensino Normal em Santa Catarina. De acordo com o referido Decreto, o normal regional tinha a duração de quatro séries anuais. Para a matrícula no primeiro ano do curso, os candidatos eram isentos da prova de admissão se apresentado o certificado de conclusão do curso primário complementar. Para as outras séries, a matrícula dependia de habilitação do ano anterior. Todavia, o artigo 101 do Decreto afirmava que os diplomados pelos antigos cursos complementares de dois anos teriam assegurada a matrícula na terceira série do curso regional, caso das irmãs que frequentaram o complementar em Rodeio. Diante dessa possibilidade, as irmãs foram incentivadas a estudar a terceira série na Congregação e prestar somente o exame final desse mesmo curso, pois, ao término de cada ano letivo, as alunas prestavam exames. E foi isso que ocorreu com as quatro candidatas citadas pela irmã Paula. Elas estudaram durante o terceiro ano na CICAF, também chamado de exame vago, fizeram o exame final e matricularam-se diretamente no quarto ano do regional ${ }^{28}$.

Irmã Maria também relembrou como foi realizado o curso: "O regional, a gente fez durante as férias. A gente fazia exames e depois só na quarta série a gente frequentou" (IRMÃ MARIA, 2014) ${ }^{29}$. Dessa maneira, algumas das irmãs conseguiram progredir nos estudos, concluindo, assim, o curso que as habilitava legalmente para dar aula na escola pública e avançar na carreira do magistério catarinense. Das irmãs entrevistadas, cinco fizeram o curso normal regional: as irmãs Dália, Paula, Maria, Geraldina e Cecília.

Em suas memórias, para frequentar o curso regional, era comum lecionarem no período da manhã e estudarem à tarde. Era importante manter as duas funções, de professora e de aluna, pois a necessidade era em ambos os aspectos. Segundo a irmã Paula, para serem promovidas na carreira docente, era indispensável, no mínimo, ter cursado o normal regional:

\footnotetext{
${ }^{28}$ Os exames vagos eram estudos parcelados, realizados nas férias, no qual as irmãs prestavam provas para prosseguir as séries cursadas. Nesse curso, a frequência era livre.

${ }^{29}$ No momento da entrevista, a Irmã Maria Venturi tinha 90 anos de idade; ela entrou na Companhia em 1942. De origem italiana, morava na localidade de Pomeranos, em Rio dos Cedros (SC), onde sua família se dedicava à agricultura familiar. Relatou que entrou na Congregação "porque era mais perto e mais fácil de entrar. Porque se fosse em outra congregação precisava de gente para levar. E, depois elas eram conhecidas pelo povo, trabalhando no nosso lugar". Quer dizer, o fato de a Congregação ser da localidade foi fator decisivo na escolha da irmã.
} 
Quando eu comecei, comecei como diarista. Depois que eu terminei o regional, daí eu fiz o concurso. O provisório era quando era diarista. No quarto ano regional, foi o concurso que se tornava efetivas. Depois do normal regional, a gente se tornava efetiva. E quem tinha feito o regional também não fazia concurso escrito, fazia concurso de títulos e tempo de serviço, assim se tornava efetiva também. Eu entrei como normalista, fazendo pelo título do diploma de normal e o tempo de serviço. (IRMÃ GERALDINA, 2014) $)^{30}$

Em 1950, foi implantado em Rodeio, o curso normal regional, sendo frequentado pelas candidatas e por algumas irmãs que as acompanhavam à escola. Isso permitiu que, em 1954, a Congregação já pudesse contar com um pequeno número de professoras normalistas, as quais auxiliavam na formação das demais. Com isso, foi possível a abertura e a oferta de formação em outras localidades: Tocos (SC), Herval d'Oeste (SC), Laurentino (SC) e Rodeio (SC), onde foi fundado um colégio pela CICAF, o Colégio Normal Madre Avosani.

O Colégio Normal Madre Avosani foi fundado em outubro de 1962, pelo Decreto $n^{\circ}$ 2.037, do Governo de Santa Catarina; no entanto, só começou a funcionar em 1963. Inicialmente, as aulas aconteciam em salas da Casa Mãe, porém, em 1971 foi inaugurado um novo prédio do Colégio Madre Avosani. Na ocasião, houve a presença do então Governador do estado de Santa Catarina, Ivo Silveira. Em 1988, esse Colégio foi fechado por dificuldades de manutenção, reduzido número de alunas e pela solicitação de um colégio com o segundo grau público (NEOTTI, 2013).

No Colégio Madre Avosani, era ofertado outro curso que apareceu nos relatos das irmãs, o "normal experimental de férias", cursado pelas irmãs Verônica e Maria31. O “curso normal experimental de férias”, segundo Neotti (2013, p. 93), foi um curso criado por uma das irmãs que estava na direção do Colégio, a irmã Irma Girardi. Neotti (2013) relata que a referida irmã teve a ideia do curso porque muitas não podiam fazê-lo durante o período escolar, por estarem em atividades em diversos municípios e tinham dificuldade de frequentar regularmente o normal. Assim, as catequistas cursavam o

\footnotetext{
${ }^{30}$ No momento da entrevista, a Irmã Geraldina Rover tinha 89 anos de idade. Entrou na Companhia em 1939, com 14 anos de idade. Sua família é de origem italiana e sempre trabalhou na lavoura. Lembrou com carinho que na infância foi aluna das Irmãs Catequistas, e isso influenciou sua escolha. Segundo seu relato, tornou-se religiosa por influência de sua professora primária.

${ }^{31}$ Mais tarde, a irmã Maria fez o normal regional e, posteriormente, o normal, que era o mais avançado do período.
} 
normal apenas nas férias, o que possibilitou a continuação dos estudos. Segundo Neotti (2013), o curso foi ofertado pela primeira vez em Santa Catarina no Colégio da Congregação, direcionado para a formação docente das irmãs e também de professoras leigas ${ }^{32}$.

As exigências legais de formação docente contribuíram para o desenvolvimento intelectual das integrantes da CICAF, pois a própria instituição teve de adequar-se ao sistema. Diante disso, duas mudanças importantes materializam-se na instituição: por um lado, a formação interna por meio da oferta de cursos, e, por outro, a possibilidade de as irmãs saírem para estudar. De acordo com Valandro (1986), em 1955, as catequistas começaram a cursar o segundo grau. Algumas eram enviadas aos colégios públicos e outras a escolas religiosas particulares, o que também possibilitou o acesso à graduação. Somente em 1959 duas irmãs concluíram o curso de graduação. Das entrevistadas, apenas duas são graduadas, as irmãs Cecília e Paula (Quadro 2).

Quadro 2 - Formação das entrevistadas ao se aposentar

\begin{tabular}{|l|l|l|}
\hline Entrevistada & $\begin{array}{l}\text { Formação no início } \\
\text { da docência }\end{array}$ & $\begin{array}{l}\text { Formação ao se } \\
\text { aposentar }\end{array}$ \\
\hline Irmã Amélia Pegoretti & Primário & Primário \\
\hline Irmã Cecília Back & Normal Regional & Graduação em Pedagogia \\
\hline Irmã Dália Tomelin & Complementar & Normal Regional \\
\hline Irmã Dorvalina Tridapalli & Primário & Normal \\
\hline Irmã Geraldina Rover & Primário & Normal \\
\hline $\begin{array}{l}\text { Irmã Jadwiga Szepanska } \\
\text { (Hedwiges) }\end{array}$ & Primário & Complementar \\
\hline Irmã Maria Venturi & Primário & Normal \\
\hline Irmã Paula Oenning & Complementar & Graduação em Pedagogia \\
\hline Irmã Violeta & Complementar & Normal \\
\hline Irmã Verônica Haskel & Primário & $\begin{array}{l}\text { “Normal Experimental de } \\
\text { Férias” }\end{array}$ \\
\hline
\end{tabular}

Fonte: Entrevistas com as irmãs concedidas a Geane Kantovitz, 2015.

Embora as irmãs dedicassem parte do seu tempo em estudos individuais e em grupos, principalmente nas férias, o exercício do magistério público exigia prova de títulos e frequência aos cursos regulares. Diante dessa exigência, além do curso

\footnotetext{
32 Embora realizada uma busca sobre mais informações do chamado "normal experimental de férias", não encontrei menção ao curso, tampouco outras escolas que o ofertaram em Santa Catarina.
} 
complementar, normal regional, normal e graduação, as Irmãs Catequistas também participavam de outros cursos para a promoção na carreira. Legalmente instituídos, esses cursos conferiam pontos para promoção 33 .

A formação professoral, aos poucos, adquiriu importância na Congregação e para as suas integrantes, e tal aspecto parecia fortalecer a identidade do grupo que se foi organizando juntamente com a formação religiosa. Era uma identidade profissional em construção mobilizada pelas tarefas cotidianas no aspecto religioso e no educacional. Nessa perspectiva, considerando que os professores "possuem saberes específicos que são mobilizados, utilizados e produzidos por eles no âmbito de suas tarefas cotidianas." (TARDIF, 2002, p. 228), as Irmãs Catequistas, inseridas num determinado contexto e em determinadas relações sociais, as quais foram mobilizadas e reafirmadas constantemente pelo discurso da CICAF, interagiam com os elementos e sujeitos principais envolvidos no processo de formação docente. As experiências vividas no grupo e pelo grupo Ihes possibilitavam construir um conjunto de saberes que orientavam suas práticas.

\section{Considerações finais}

Pensar no processo formativo das Irmãs Catequistas implica pensar nas rupturas e nas continuidades do ato de formar-se professora, isto é, consideram-se as tipificações docentes construídas na formação inicial e (re)produzidas durante toda a carreira docente, partes fundamentais na constituição de um profissional. Todavia, essas tipificações não são estáticas, são constantemente produzidas e reconstruídas de acordo com as interações sociais, as práticas do cotidiano, da experiência vivida e das mudanças propostas.

\footnotetext{
33 De acordo com Valandro (1990), esses títulos também dependiam da participação das professoras em reuniões mensais. No entanto, frei Bruno considerou o fato de as Irmãs saírem mensalmente sumamente perigoso para a vida religiosa. Em 1939, ele escreve no Livro da Crônica uma página com recomendações, proibições e normas, sobre a maneira como deveriam proceder naquelas reuniões: "É pois, de suma importância para as Catequistas, nestas reuniões, que conservem o espírito apostólico. Devem ficar numa casa religiosa e, não tendo casa religiosa, não podem ficar em outra casa nem de dia e muito menos à noite. Devem ser tidas como perigosíssimas as conversas com seculares [...] terminada a reunião, as Catequistas se retiram imediatamente, sem cumprimentos mundanos e se recolhem na casa indicada pela superiora. Toda e qualquer Catequista falte antes à reunião do que a tal salutar aviso" (LIVRO DAS CRÔNICAS DA CONGREGAÇÃO, 1939 apud VALANDRO, 1990, p. 198).
} 
A formação docente das integrantes da CICAF foi um dos mais importantes mecanismos de legitimação da presença dessas irmãs no cenário educacional primário de Santa Catarina no século XX. Para que pudessem permanecer nas escolas públicas estaduais e/ou municipais, a formação docente era um importante critério para garantir a plausibilidade da realidade social.

Nas narrativas das entrevistadas, ficaram evidentes alguns apontamentos sobre a sua formação. Em primeiro lugar, a formação docente contribuiu para a efetivação dessas professoras na carreira pública no Estado, pois elas atendiam à carência de professores em escolas mais distantes, principalmente localizadas nas áreas rurais que apresentavam falta de docentes. Em segundo lugar, percebeu-se que a formação docente era articulada à identidade religiosa, isto é, ser professora catequista era, acima de tudo, ser também religiosa; eram processos intrinsicamente relacionados, afinal, era a legitimidade do grupo de pertencimento que estava em jogo. A dimensão significativa da formação docente estava diretamente relacionada à formação religiosa num movimento dialético, o qual, gradativamente, foi consolidando uma identidade professoral específica das integrantes da CICAF. Constituíram-se professoras não somente nos momentos de formação, oportunizados pela CICAF ou pelo poder público, mas, sobretudo, no cotidiano escolar de sua prática pedagógica. Elas não só desempenharam o papel de religiosas ou de professoras, mas eram de fato religiosas e professoras inseridas em determinada ordem social. 


\section{Referências}

BEIRITH, Ângela. As escolas isoladas de Florianópolis no contexto da regulamentação do ensino primário (1946-1956). Revista Linhas, Florianópolis, v. 10, n. 2, p. 156-168, jul./dez. 2009.

BENEDUZI, Luis Fernando. Imigração italiana e catolicismo: entrecruzando olhares, discutindo mitos. Porto Alegre: EDIPUCRS, 2008.

BERGER, Peter Ludwing; LUCKMANN, Thomas. A construção social da realidade: tratado de sociologia do conhecimento. Tradução: Floriano de Sousa Fernandes. Petrópolis: Vozes, 1985.

BOMBASSARO, Ticiana. As "semanas educacionais": arquitetura do poder sob a celebração da didática. Revista Educação, Santa Maria, v. 35, n. 2, p. 315-328, maio/ago. 2010.

BOMBASSARO, Ticiana; SILVA, Vera Lucia Gaspar da. Modernização do Estado e Reformas do Ensino: manifestações da Escola Nova em Santa Catarina. In: MIGUEL, Maria Elisabeth Blanck; VIDAL, Diana Gonçalvez; ARAUJO, José Carlos Souza. Reformas Educacionais: as manifestações da Escola Nova no Brasil (1920 a 1946). Campinas: Autores Associados; Uberlândia: EDUFU, 2011.

BRASIL. Decreto $n^{\circ}$ 8.530, de 2 de janeiro de 1946. Dispõe sobre a Lei Orgânica do Ensino Normal. Brasília: Presidência da República, 1946.

BRUNELLI, Delir. Maria Avosani. In: CÂNDIDO, Edinei da Rosa (org.). Cadernos Patrísticos: textos e estudos. Florianópolis, v. 3, n. 5, p. 297-310, maio 2008.

CARVALHO, Marta Maria Chagas de. Uso do impresso nas estratégias católicas de conformação do campo doutrinário da pedagogia (1931-1935). Cadernos Anped, Belo Horizonte, n. 7, p. 41-60, dez. 1994.

CUNHA, Maria Tereza Santos; OLIVEIRA JUNIOR, Joeci. O intelectual Elpídio Barbosa: analisando a sua atuação no cenário educacional de Santa Catarina nas décadas de 1940 e 1950. In: SEMINÁRIO DE INICIAÇÃO CIENTÍFICA, 25, 2015, Florianópolis. Anais [...]. Florianópolis: [s.n.], 2015. p. 1-2.

DALLABRIDA, Norberto. À sombra do campanário: o catolicismo romanizado na área de colonização italiana do Médio Vale do Itajaí-Açu (1892-1918). 1993. 221 f. Dissertação (Mestrado em História) - Centro de Filosofia e História, Universidade Federal de Santa Catarina, Florianópolis, 1993.

FERREIRA, Marieta de Moraes; AMADO, Janaína. Usos e abusos da história oral. 8. ed. Rio de Janeiro: FGV, 2006. 
FIORI, Neide Almeida. Aspectos da evolução do ensino público: ensino público e política de assimilação cultural no estado de Santa Catarina nos períodos Imperial e Republicano. 2. ed. rev. Florianópolis: UFSC, 1991.

GASCHO, Maria de Lourdes. Catequistas franciscanas: uma antecipação do "aggiornamento" em Santa Catarina (1915-1965). 1998. 174 f. Dissertação (Mestrado em História) - Centro de Filosofia e História, Universidade Federal de Santa Catarina, Florianópolis, 1998.

HALBWACHS, Maurice. A memória coletiva. Tradução: Beatriz Sidou. São Paulo: Centauro, 2003.

IRMÃ DÁLIA. Entrevista cedida a Geane Kantovitz. Rio do Sul (SC), 24 de setembro de 2014.

IRMÃ GERALDINA. Entrevista cedida a Geane Kantovitz. Rio dos Cedros (SC), 12 de setembro de 2014.

IRMÃ HEDWIGES. Entrevista cedida a Geane Kantovitz. Rodeio (SC), 22 de setembro de 2014.

IRMÃ MARIA. Entrevista cedida a Geane Kantovitz. Rio do Sul (SC), 24 de setembro de 2014 .

IRMÃ PAULA. Entrevista cedida a Geane Kantovitz. Laurentino (SC), 23 e 24 de setembro de 2014 .

IRMÃ VIOLETA. Entrevista cedida a Geane Kantovitz. Rodeio (SC), 15 de janeiro de 2015. LEONARDI, Paula. Além dos espelhos: memórias, imagens e trabalhos de duas congregações católicas. São Paulo: Fapesp: Paulinas, 2010.

LIVRO TOMBO I. Livro Tombo São Francisco de Assis. Rodeio: [s.n.], 1942.

NEOTTI, Augusta. Nos trilhos da história. Blumenau: 3 de Maio Ltda., 2013.

NUNES, Maria Jose Rosado. Freiras no Brasil. In: PRIORI, Mary del. História das mulheres no Brasil. São Paulo: Contexto. 2010.

OTTO, Clarícia. Catolicidades e italianidades: tramas e poder em Santa Catarina (18751930). Florianópolis: Insular, 2006.

OTTO, Clarícia. Escolas étnicas italianas no sul do Brasil: entre tensões e conciliações. In: SIMPÓSIO NACIONAL DE HISTÓRIA, 26, 2011, São Paulo. Anais [...]. São Paulo: USP, 2011. p. 1-17.

OTTO, Clarícia. Do professor paroquial às professoras catequistas: notas para a história da educação em Santa Catarina. História Unisinos, Rio Grande do Sul, v. 16, n. 3, p. 403412, set./dez. 2012 a. 
OTTO, Clarícia. Professoras a serviço da Igreja e do Estado: tensões e conciliações em tempos de nacionalização do ensino. Revista Brasileira de História das Religiões, Maringá, v. 5, n. 14, p. 167-183, set. 2012b.

OTTO, Clarícia; SOUZA, Rogério Luiz de (org.). Faces do catolicismo. Florianópilis: [s.n.], 2008. p. 171-191.

PEREIRA, Elaine Aparecida Teixeira; DAROS, Maria das dores. Princípios da escola nova na educação catarinense em meados do século XX: olhares de João Roberto Moreira e Orlando Ferreira de Melo. In: COLÓQUIO ENSINO MÉDIO, HISTÓRIA E CIDADANIA, 8, 2013, Florianópolis. Anais [...]. Florianópolis: Universidade Federal de Santa Catarina, 2013. p. 1-13.

PINHEIRO, Ana Regina; BITTENCOURT, Agueda Bernadete. Dossiê apresentação. políticas católicas: educação, arte e religião. Revista Brasileira de História da Educação, Maringá, v. 15, p. 159-168, 2015.

POLLAK, Michael. Memória, esquecimento, silêncio. Estudos Históricos, Rio de Janeiro, v. 2, n. 3, p. 3-15, 1989.

POLLAK, Michael. Memória e Identidade Social. Estudos Históricos, Rio de Janeiro, v. 5, n. 10, p. 200-212, 1992.

PRATES, Fernanda Ramos Oliveira; OLIVEIRA, Julia Vieira Tocchitto de; TEIVE, Gladys Mary Ghizoni. Associações auxiliares da escola: vestígios de sua incorporação à cultura dos grupos Escolares Lauro Müller e Alberto Torres (1946 e 1956). In: SEMINÁRIO DE PESQUISA EM EDUCAÇÃO DA REGIÃO SUL, 9, 2012, Caxias do Sul. Anais [...]. Caxias do Sul: Universidade de Caxias do Sul, 2012. p. 1-16.

SANTA CATARINA. Decreto $\mathbf{n}^{\circ}$ 572, de 25 de fevereiro de 1911. Programma de Admissão. Florianópolis, SC: [Governo do Estado de Santa Catarina], 25 fev. $1911 a$.

SANTA CATARINA. Decreto $\mathbf{n}^{\circ} \mathbf{1 . 3 2 2 ,}$ de 29 janeiro de 1920. Trata do programma dos grupos escolares e das escolas isoladas do estado de Santa Catharina. Florianópolis, SC, [Governo do Estado de Santa Catarina], 1920.

SANTA CATARINA. Decreto $\mathbf{n}^{\circ} \mathbf{5 8}$, de 28 de janeiro de 1931. Trata da atual legislação escolar, relativa à nacionalização do ensino primário e ao ensino privado. Florianópolis, SC, [Governo do Estado de Santa Catarina], 1931.

SANTA CATARINA. Decreto $\mathbf{n}^{\circ} \mathbf{7 1 3}$, de 5 de janeiro de 1935. Dispõe sobre as normas que regem os Institutos destinados à formação de professorado, para aplicação dos novos métodos de ensino. Coleção de Leis e Decretos do Estado de Santa Catarina.

Florianópolis, SC, [Governo do Estado de Santa Catarina], 1935.

SANTA CATARINA. Decreto ${ }^{\circ}$ 298, de 18 de novembro de 1946. Expede a Lei Orgânica do Ensino Primário. Diário Oficial n³.349, Florianópolis, SC, p. 1-4, 18 nov. 1946 a. 
SANTA CATARINA. Decreto $n^{\circ} 257$, de 21 de outubro de 1946. Expede a Lei Orgânica do Ensino Normal no Estado de Santa Catharina. Coleção de Leis e Decretos do Estado de Santa Catarina. Florianópolis, SC: [s.n.], 1946 b.

SANTA CATARINA. Decreto $\mathbf{n}^{\circ}$ 3.732, de 12 de dezembro de 1946. Expede o programma para os estabelecimentos de Ensino Primário do Estado de Santa Catharina. Florianópolis, SC, [Governo do Estado de Santa Catarina], 1946c.

SANTA CATARINA. Decreto $\mathbf{n}^{\circ} \mathbf{3 . 7 3 3}$, de dezembro de 1946 . Expede o regulamento para o Serviço de Inspeção Escolar. Florianópolis, SC, [Governo do Estado de Santa Catarina], 1946d.

SANTA CATARINA. Decreto $\mathbf{n}^{\circ} \mathbf{3 . 7 3 5}$, de dezembro de 1946. Expede o regulamento para os estabelecimentos de ensino primário. Florianópolis, SC, [Governo do Estado de Santa Catarina], 1946e.

SEIDT, Ernesto. Escola, religião e comunidade: elementos para compreensão do “catolicismo imigrante”. Pensamento Plural, Pelotas, v. 3, p. 77-104, jul./dez. 2008.

SOUZA, Rogério Luiz. As Escolas Paroquiais. In: DALLABRIDA, Norberto (org.). Mosaico de escolas: modos de educação em Santa Catarina na Primeira República. Florianópolis: Cidade Futura, 2003.

TARDIF, Maurice. Saberes docentes e formação profissional. Tradução: Francisco Pereira. Petrópolis: Vozes, 2002.

VALANDRO, Ede Maria. Um chamado se faz caminho: evolução histórica do carisma. Joinville: [s.n.], 1986. Congregação das Irmãs Catequistas Franciscanas.

VALANDRO, Ede Maria. Em resposta ao clamor do povo: a Congregação das Irmãs Catequistas Franciscanas. Joinville: [s.n.], 1990. Congregação das Irmãs Catequistas Franciscanas.

Recebido em: 02/04/2018 Revisões requeridas em: 07/06/2019 Aprovado em: 06/12/2019

Universidade do Estado de Santa Catarina - UDESC Programa de Pós-Graduação em Educação - PPGE Revista Linhas

Volume 21 - Número 46 - Ano 2020 revistalinhas@gmail.com 